the ICU were found to be significantly more comorbid, having significantly higher proportions of hypertension (41\% vs $59 \%, \mathrm{p}=0.005)$, diabetes mellitus $(18 \%$ vs $38 \%, \mathrm{p}<0.001)$, COPD $(13 \%$ vs $28 \%, p=0.008)$, asthma $(8 \%$ vs $18 \%$, $\mathrm{p}=0.031)$, ischaemic heart disease $(11 \%$ vs $27 \%, \mathrm{p}=0.003)$, and a history of smoking $(33 \%$ vs $59 \%, \mathrm{p}<0.001)$. We do not report any differences in the duration of treatment with CPAP.

Conclusions In our report we found that inpatient mortality of those treated inside of the ICU was significantly lower than that of those treated outside of this setting, however, those

Abstract P211 Table 1 Displaying baseline characteristics, physiological observations, laboratory tests, and outcomes of all patients treated with CPAP and comparing these observations between those treated inside and outside of the ICU

\begin{tabular}{|c|c|c|c|c|}
\hline & $\begin{array}{l}\text { All Patients } \\
(\mathrm{n}=187)\end{array}$ & $\begin{array}{l}\text { ICU } \\
(n=90)\end{array}$ & $\begin{array}{l}\text { Non-ICU } \\
(n=97)\end{array}$ & p-value \\
\hline Age - Mean (SD) & $66.1(12.7)$ & $\begin{array}{l}61.2 \\
(13.9)\end{array}$ & $70.9(11.8)$ & $<0.001$ \\
\hline Male - n (\%) & $120(64)$ & $57(63)$ & $63(65)$ & 0.530 \\
\hline $\begin{array}{l}\text { CPAP duration in days - Median } \\
\text { (range) }\end{array}$ & $4(1-48)$ & $4(1-20)$ & $4(1-48)$ & 0.356 \\
\hline Inpatient Death - n (\%) & $84(45)$ & $26(29)$ & $58(60)$ & $<0.001$ \\
\hline \multicolumn{5}{|l|}{ Comorbidities - n (\%) } \\
\hline HTN & $94(50)$ & $37(41)$ & $57(59)$ & 0.005 \\
\hline Diabetes Mellitus & $53(28)$ & $16(18)$ & $37(38)$ & $<0.001$ \\
\hline COPD & $39(21)$ & $12(13)$ & $27(28)$ & 0.008 \\
\hline Asthma & $24(13)$ & $7(8)$ & $17(18)$ & 0.031 \\
\hline IHD & $36(19)$ & $10(11)$ & $26(27)$ & 0.003 \\
\hline Smoking History & $87(47)$ & $30(33)$ & $57(59)$ & $<0.001$ \\
\hline Obesity & $69(37)$ & $36(40)$ & $33(34)$ & 0.108 \\
\hline \multicolumn{5}{|l|}{ Laboratory Results - Mean (SD) } \\
\hline Admission WCC $-\times 10^{9} / \mathrm{L}$ & $9.8(4.4)$ & $\begin{array}{l}11.0 \\
(6.3)\end{array}$ & $8.8(4.2)$ & 0.016 \\
\hline Admission lymphocyte count $-x 10^{9} / \mathrm{L}$ & $1.25(0.64)$ & $\begin{array}{l}1.94 \\
(0.81)\end{array}$ & $1.18(0.95)$ & 0.190 \\
\hline Admission Urea - mmol/L & $9.3(6.7)$ & $7.8(4.2)$ & $10.6(7.8)$ & 0.006 \\
\hline Admission C-reactive Protein - mg/L & $135.8(101.5)$ & $\begin{array}{l}135.2 \\
(102.0)\end{array}$ & $\begin{array}{l}130.1 \\
(90.8)\end{array}$ & 0.750 \\
\hline \multicolumn{5}{|l|}{$\begin{array}{l}\text { Observations pre-CPAP - Mean } \\
\text { (SD) }\end{array}$} \\
\hline Respiratory Rate & $25.8(6.4)$ & $\begin{array}{l}26.4 \\
(6.9)\end{array}$ & $25.7(6.0)$ & 0.345 \\
\hline Heart Rate & $92.4(20.4)$ & $\begin{array}{l}96.9 \\
(21.7)\end{array}$ & $89.8(19.7)$ & 0.044 \\
\hline Oxygen Saturations & $88.8(7.1)$ & $\begin{array}{l}88.7 \\
(7.3)\end{array}$ & $88.4(6.7)$ & 0.280 \\
\hline $\mathrm{FiO2}-\%$ & $59.9(22.9)$ & $\begin{array}{l}58.9 \\
(32.3)\end{array}$ & $66.1(17.5)$ & 0.074 \\
\hline \multicolumn{5}{|l|}{$\begin{array}{l}\text { Arterial Blood Gas Results pre- } \\
\text { CPAP - Mean (SD) }\end{array}$} \\
\hline Arterial pH & $7.44(0.08)$ & $\begin{array}{l}7.45 \\
(0.07)\end{array}$ & $7.44(0.07)$ & 0.484 \\
\hline Arterial p02 - kPa & $7.4(1.4)$ & $7.4(1.3)$ & $7.4(1.5)$ & 0.796 \\
\hline Arterial Base Excess - $\mathrm{mmol} / \mathrm{L}$ & $0.6(4.9)$ & $0.7(3.6)$ & $0.5(5.0)$ & 0.813 \\
\hline
\end{tabular}

treated in the ICU were also significantly younger and had fewer comorbidities. Despite the higher mortality outside of the ICU, $40 \%$ of patients treated in this setting survived to discharge, this may suggest that those who may be deemed unsuitable for treatment with CPAP on the ICU can be managed safely outside of this setting.

\section{P212 NON-INVASIVE RESPIRATORY SUPPORT IN ADULTS WITH COVID-19 WHO ARE NOT FOR INTUBATION: THE BALANCE BETWEEN SAVING LIVES AND PROLONGING DEATH}

SB Naidu, ASC Lawrence, A Kirupananthavel, A Nijhawan, A Gupta, J Fretwell, TL Sutton, K Matsumoto, Z Thursz, DJ Hobden, A Saleh, F Rashid, I Whelan, M Darmalingam. Barts Health London NHS Trust, London, UK

\subsection{6/thorax-2021-BTSabstracts.321}

Introduction Non-invasive respiratory support (NIRS) has been used in adults with COVID-19 who are not for intubation (DNI), but mortality in this group was as high as $89 \%$ in the first wave (1). To our knowledge, there is no data on outcomes after advances such as steroids, and on factors associated with effective NIRS in this group.

Methods We retrospectively collected data on all adults with COVID-19 who were treated with NIRS between 17/9/2020 and 30/1/2021 during the 'second wave' in our hospital. Logistic regression was used to review the multi-variate association between mortality and investigated factors.

Results In our respiratory wards, 309 adults received NIRS, of whom 106 had a DNI.

Adults with a DNI were older and more multi-morbid (see Table 1). Mortality in adults with a DNI compared to those without was significantly higher $(74.5 \%$ vs. $26.2 \%$, pvalue $<0.001$; odds ratio (OR) $8.20,95 \%$ confidence interval (CI) 4.78-14.21), even after adjusting for age and comorbidities (OR 3.03, 95\% CI 1.35-6.81).

There were few factors which predicted effective NIRS in this group (see table 1). 92.1\% of 38 adults who received sedatives to improve tolerance died.

Discussion Even allowing for age and multi-morbidity and despite advances in treating COVID-19, mortality remains high at $74.5 \%$ for adults with a DNI who require NIRS.

There is little guidance on using NIRS in this group, with one large clinical trial excluding adults with a DNI (2). NIRS has disadvantages; it may present a significant treatment burden and patients who required sedation to aid compliance had higher mortality. Furthermore, there are few factors to guide which patients benefit. There are thus ethical implications to offering NIRS, especially in resourcestrained settings.

More research is urgently required in this group, especially for future waves. Meanwhile, clinicians should sensitively discuss the risks of treatment failure and involve palliative care to help manage distressing symptoms such as breathlessness and anxiety.

\section{REFERENCES}

1. Vaschetto R, et al. Outcomes of COVID-19 patients treated with continuous positive airway pressure outside the intensive care unit. ERJ Open Res 2021 doi:10.1183/23120541.00541-2020

2. RECOVERY-RS Respiratory support: respiratory strategies in COVID-19 trial protocol. 
Abstract P212 Table 1 Demographic, co-morbidities, treatment and outcome data

\begin{tabular}{|c|c|c|c|}
\hline \multicolumn{4}{|c|}{ Data for all patients treated with CPAP/HFNO on respiratory wards for COVID-19 } \\
\hline & $\begin{array}{l}\text { Adults for } \\
\text { intubation } \\
(n=203)\end{array}$ & $\begin{array}{l}\text { Adults not for } \\
\text { intubation (DNI) } \\
(n=106)\end{array}$ & $\mathrm{p}$-value \\
\hline & \multicolumn{3}{|c|}{ Demographics and co-morbidities } \\
\hline Age $^{*}$ & $60.3( \pm 12.6)$ & $76.3( \pm 11.4)$ & $<0.001$ \\
\hline Male sex (\%) & 68.8 & 57.5 & 0.049 \\
\hline Black, Asian \& Minority & 61.1 & 48.1 & 0.029 \\
\hline \multicolumn{4}{|l|}{ Ethnic (\%) } \\
\hline Body mass index* & $29.8( \pm 5.7)$ & $29.7( \pm 9.7)$ & 0.95 \\
\hline Diabetes (\%) & 30.2 & 41.5 & 0.047 \\
\hline Cardiovascular disease (\%) & 49.5 & 69.8 & $<0.001$ \\
\hline \multicolumn{4}{|l|}{ (\%) } \\
\hline Mental health disease (\%) & 7.9 & 18.9 & 0.04 \\
\hline Smoking history (\%) & 34.0 & 41.9 & 0.277 \\
\hline Charlson co-morbidity index & $3(2-5)$ & $3(2-5)$ & 0.956 \\
\hline \multirow[t]{2}{*}{ Clinical frailty score } & $3(2-4)$ & $5(4-6)$ & $<0.001$ \\
\hline & \multicolumn{3}{|c|}{ Admission data and outcomes } \\
\hline $\begin{array}{l}\text { Day of COVID-19 symptoms } \\
\text { on admission to respiratory } \\
\text { ward }\end{array}$ & $9(7-12)$ & $8(5.5-12)$ & 0.119 \\
\hline \multicolumn{4}{|l|}{$(\%)$} \\
\hline Treated with remdesivir (\%) & 37.1 & 29.5 & 0.184 \\
\hline Treated with tocilizumab (\%) & 10.4 & 4.7 & 0.089 \\
\hline Died (\%) & 25.6 & 74.5 & $<0.001$ \\
\hline \multicolumn{4}{|c|}{ Factors associated with mortality in adults with DNI treated with CPAP/HFNO } \\
\hline & Odds ratio & $\begin{array}{l}95 \% \text { lower } \\
\text { confidence } \\
\text { interval }\end{array}$ & $\begin{array}{l}95 \% \text { upper } \\
\text { confidence } \\
\text { interval }\end{array}$ \\
\hline Age & 1.04 & 1.00 & 1.09 \\
\hline Male sex & 2.51 & 1.03 & 6.13 \\
\hline Black, Asian \& Minority & 1.00 & 0.41 & 2.40 \\
\hline \multicolumn{4}{|l|}{ Ethnic } \\
\hline Body mass index & 0.99 & 0.95 & 1.04 \\
\hline Diabetes & 1.28 & 0.52 & 3.16 \\
\hline Cardiovascular disease & 0.76 & 0.28 & 2.02 \\
\hline Chronic respiratory disease & 0.99 & 0.41 & 2.41 \\
\hline Mental health disease & 0.75 & 0.26 & 2.21 \\
\hline Smoking history & 1.40 & 0.41 & 4.80 \\
\hline Charlson co-morbidity index & 1.02 & 0.85 & 1.22 \\
\hline Clinical frailty score & 1.06 & 0.73 & 1.54 \\
\hline Treated with remdesivir & 0.73 & 0.28 & 1.88 \\
\hline Treated with tocilizumab & 1.39 & 0.15 & 12.98 \\
\hline Given sedatives & 4.35 & 1.37 & 13.82 \\
\hline
\end{tabular}

*Presented as mean with standard deviation. Non-parametric data presented as median with IQR.
Introduction Respiratory failure in COVID pneumonia is often associated with ARDS. Invasive mechanical ventilation (IMV) is associated with high mortality and prolonged hospital stay. Continuous positive airways pressure (CPAP) has emerged as a bridge to IMV or as ceiling of care in patients with high clinical frailty scale (CFS).

Methods We retrospectively analysed data of patients admitted our respiratory support unit (RSU) between September 2020 till January 2021. Patients admitted to our RSU received CPAP, High flow nasal oxygen( HFNO) and non invasive ventilation (NIV).

Results 118 patients were included in the analysis. Mean age was 71 years with $61 \%(\mathrm{n}=72)$ comprising of male patients. 77 patients $(65 \%)$ patients receiving respiratory support (RS) died. $80(67 \%)$ patients had more 2 or more co morbidities. $60 \%(\mathrm{n}=71)$ and $20.3 \%(\mathrm{n}=24)$ received CPAP and HFNO as predominant modality respectively. Mean CFS was 4.3 in survival group as compared to 4.7 in survival group (p $1.98) .88 \%$ patients $(n=67)$ who died were aged above 65 . Average time on RS was 7.5 days and length of stay (LOS) was 12.5 days. RS compliance was higher in survival group $85 \%(n=35)$ as compared to deceased group $42 \%(n=32)$. Time on RS in survival and deceased group were comparable 7.2 days and 8.4 days respectively ( $p$ 1.98). Time from positive PCR test to start of RS was lower in survival group (2.9 days vs 2 days, p 0.18). Mean D Dimers were 1.7 in survival group as compared to deceased group 3.5 ( $\mathrm{p} 0.18$ ). Use of syringe driver was high in deceased group $(66 \% \mathrm{n}=51)$ as compared to survival group $(n=2)$. Mean BMI was higher in survival group (33.9 vs 28.7 , p 0.001 )

\begin{tabular}{llll} 
Abstract P213 Table 1 & & \\
\hline & $\begin{array}{l}\text { CPAP } \\
\text { survived }\end{array}$ & $\begin{array}{l}\text { CPAP } \\
\text { Deceased }\end{array}$ & P value \\
\hline Age & 62 & 77 & $0.000004^{*}$ \\
BMI & 33 & 28.7 & $0.001^{*}$ \\
CFS & 4.3 & 4.7 & 1.98 \\
CRP & 89 & 136 & $0.004^{*}$ \\
D Dimer & 1.7 & 3.6 & 0.18 \\
Troponin & 325 & 125 & 0.19 \\
Time to start RS & 2 & 2.9 & 0.10 \\
(days) & & & 0.42 \\
Length of stay(days) & 13.4 & 12.1 & 1.98 \\
Days on RS (days) & 8.4 & 7.2 & \\
\hline * $p<0.05=$ statistically significant & & \\
\hline
\end{tabular}

Discussion Age, high CFS, and poor compliance with CPAP is associated with higher mortality in COVID 19 related ARDS. Further studies are needed to assess impact of troponin and D Dimer on COVID related ARDS outcomes.

\section{P214 COVID-19 MORTALITY RATES IN A DISTRICT GENERAL RESPIRATORY SUPPORT UNIT}

A Yousuf, M Selvan, SH Lee, P Hawkins, R Badiger. Colchester General Hospital, Colchester, UK

10.1136/thorax-2021-BTSabstracts.323 